\title{
Capacity Side of the Point Evaluation Utilizing Programming Item Estimation
}

\author{
Shanmugapriya.K, Mary Linda.I, Geetha.C.
}

\begin{abstract}
In programming industry FPA is utilized for assessing the highlights of programming ventures. The highlights are cost, span, exertion and so forth. The product achievement elements are quicker, better and less expensive. In programming improvement process, the achievement depends on undertaking arranging and estimation. Estimation is the determined guess of the aftereffect of explicit issue. It lead significant job is task arranging. One of the real estimation and measuring procedure is FPA. It is useful for evaluating the highlights of created ventures. In any case, it isn't precise for evaluating the highlights of activities to be created. So here the idea of similarity estimation and PERT are included with FPA and present another method EFPA. It can give progressively precise appraisals. It is valuable for the product business for assessing the highlights of programming.

Keywords : FPA- Function Point Analysis, EFPA- Extended function point analysis.
\end{abstract}

\section{INTRODUCTION}

Programming designing is a methodical creation and support of programming that is created and adjusted on time with in cost estimation. Viable estimation based arranging is to be give achievement in programming improvement. The product improvement procedure comprises of examination, structure, coding, testing and support. In examination stage catch all necessities, to build an underlying plan of action and to finish the arrangement to build up the undertaking. The arranging procedure begins with an appraisal of the limitations (required conveyance date, staff, generally speaking spending plan and so on) influencing the undertaking. This is done in

combination with an estimation of undertaking parameters, for example, its structure, size and circulation of capacities.[1][2]

\section{PROJECT PLANNING ALGORITHM:}

1. Set up the test requirements.

2. Make beginning checks of the test parameters.

3. Characterize task achievements and expectations.

4. While adventure has now not been finished do the accompanying advances generally dropped the circle

Revised Manuscript Received on August 22, 2019.

Shanmugapriya.K Assistant Professor, Department of Computer Science and Engineering,, Bharath Institute of Higher Education and Research, Chennai, India

Mary Linda.I Assistant Professor, Department of Computer Science and Engineering,, Bharath Institute of Higher Education and Research, Chennai, India

Geetha.C, Assistant Professor, Department of Computer Science and Engineering,, Bharath Institute of Higher Education and Research, Chennai, India

I. Draw up errand time table.

II. Initiate sports in venture with the timetable

III. Review venture advancement.

IV. Revisae assessments of endeavor parameters

V. Update the mission plan

VI. Renegotiate mission imperatives and expectations.

VII. If (issue ascend) at that point

Start specialized evaluation

furthermore, plausible update

Endif

End Loop. The above expressed undertaking arranging calculation states programming estimation is significant movement. The disappointment of numerous enormous programming activities featured the issue of lack of common sense and estimation.

\section{ACTIVITIES DURING SOFTWARE PROJECT PLANNING}

The major activities in project planning stage is Estimation, Requirements capturing, Project scheduling. The below figure shows these activities.

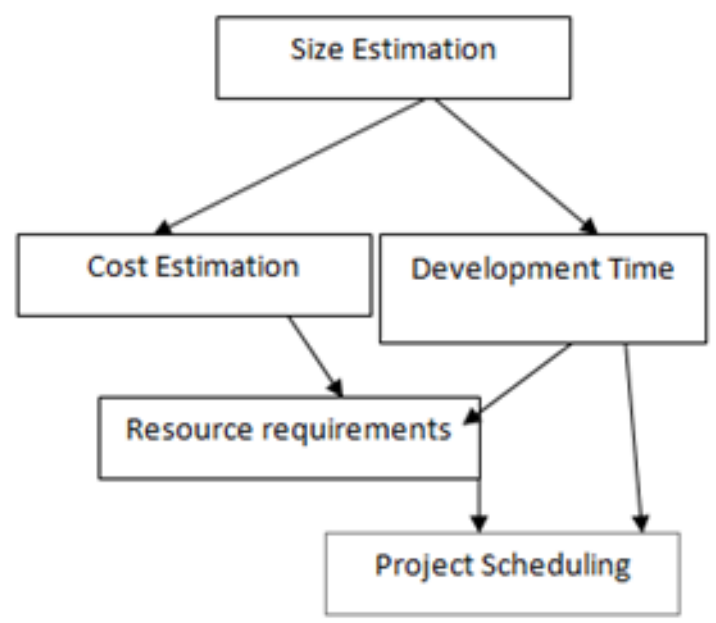

(Fig 1. Activities during software projectplanning)

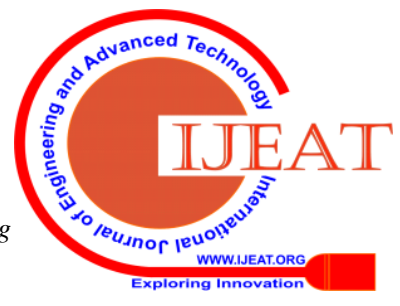




\section{ESTIMATION BY ANALOGY}

Bhom portray this estimation as "similarity estimation". This depends on estimation strategy depicted by Ray Wolverton that attempts to distinguish similitudes and contrasts between undertakings [1974]. Quantitativesimilarity strategies are straightforward approach to change authentic qualities. Specialists measure how much distinction the estimation of new item identified with the estimation of known article. To assess the distinctions specialists can utilize the Delphitechnique, past experience or some other strategy. Apply the assessed contrasts additively or multiplicatively. This two similarity methods are an improvement over the fundamental Delphi procedure.[3-15]

\section{A. Additive analogy:}

The estimator includes or subtract limited quantity from a known (recorded) worth to compute the evaluated an incentive for the new article. Randall Jensen portrays a comparative system called "relative correlation"

\section{B. Multiplicative analogy}

Proportion scaling applies to an amount for estimation. Decide the rates of each factor utilizing PERT or Delphi strategy.

\section{c. Algorithmic analogy}

This technique has fundamental activities :

1. Define the technique

Define a facts set . Define degree for every characteristic and for the amount.

Collect facts set for multiple existing times

Validate the information

Define an algorithm to degree the degree of similarity among times

Define an set of rules to pick out the closest neighbors for the brand new instance.

Define an set of rules to calculate the price of the new instance.[25-30]

\section{Apply the method}

Specify the characteristics of the new item.

Locate and choose the desired numbers of nearest neighbors. Combine the values from the associates to get the price to be estimate.

Adrian Cowderoy and Joh Jenkins depicted one of the primary organized methodologies for utilizing analogies for estimation. They carefully representing programming or framework estimation; the analogies apply to objects in an equivalent issue area. This is all the more appropriately called case based thinking.

\section{PERT(PROGRAM EVALUATION AND REVIEW TECHNIQUE)}

Lockheed and US Navy built up this strategy in late 1950's. Lawrence Putnam and Anne Fitzsimmons connected it to programming in 1979. Saucy method utilizes extra data from the estimator to create a superior gauge. The estimator gives three evaluations to the amount of intrigue.

Using these three values PERT technique calculates the expected value $\mathrm{E}$ and standard deviation $\sigma$.

$$
\mathrm{E}=(\mathrm{L}+4 * \mathrm{M}+\mathrm{H}) / 6
$$

(E - Estimate of the average value)

$$
\sigma=(\mathrm{H}-\mathrm{L}) / 6
$$

\section{FPA(FUNCTION POINT ANALYSIS)}

Function count:

Rather than line to discover number of capacities in a program for assessing cost, improvement time, staff and exertion. FPA is a procedure used to assess programming utilizing capacity tally.

FPA measures usefulness from client's perspective. That is based on what the client demand and gets consequently from the framework. The equation for computing capacity point is UDP is determined dependent on the useful units and weight factors. UFP equivalents to entirety of result of practical units and weighting factors. The practical units are

Outer Input(EI), External output(EO), External Inquiry(EQ), Internal sensible files(ILF), External legitimate files(ELF).The weighting components are low normal and high.The following table shows functional units and weighting factors.

\begin{tabular}{|c|c|c|c|}
\hline \multirow{2}{*}{$\begin{array}{l}\text { Functional } \\
\text { Units }\end{array}$} & \multicolumn{3}{|c|}{ Weighting factors } \\
\cline { 2 - 4 } & LOW & AVERAGE & HIGH \\
\hline EI & 3 & 4 & 6 \\
\hline EO & 4 & 7 & 7 \\
\hline EQ & 3 & 4 & 6 \\
\hline ILF & 7 & 10 & 15 \\
\hline ELF & 5 & 7 & 10 \\
\hline
\end{tabular}

(Table 1: functional units and weighting factors)

$\mathrm{CAF}$ is equal to

$0.65+0.01 * \sum \mathrm{Fi}$

$\mathrm{Fi}(\mathrm{i}=1$ to14)

There are 14 adjustment factors

The complexity adjustment factors describe 14 system characteristics. They are

- Data Communication

- Distributed data processing

- Performance

- Heavily used configuration

- Transaction rate

Using function points we can assess productivity,estimate cost, quality and documentation. It may compute[16-19]

\section{PROPOSED SYSTEM}

Existing function point analysis is good for estimating the features of developed software. But it is not accurate for estimating the features of software to be developed. Any effective estimation past experience and historical information are necessary. Algorithmic Analogy Estimation stated the same for estimation. 
So here the combined technique FPA and Algorithmic Analogy called EFPA is suggested for estimating the features of software to be developed.[20-25]

\section{INITIAL SCENARIO FOR THE PROPOSED SYSTEM}

1. Maintain the database for completed projects and their features.

\begin{tabular}{l}
\hline Name \\
\hline EI
\end{tabular}

2.If the new project is similar to the projects in the existing database then choose the features of existing project.

3. Analyze the Features of new and existing project. (EI, EO, EQ, ILF, ELF)

4. Choose the most likely value of feature by using PERT technique or by using additive or multiplicative analogy.

5. Validate the data

6. Calculate CAF, UFP and FP.

7. Calculate cost, duration and other features.

\section{CONCLUSION}

Implementation of FPA is the good solution of finding features of the project to be developed. The past experience and historical information will give effective inputs for determining the features of the software. So it provides accurate estimates.

\section{REFERENCES}

1. Gowri Sankaran, B., Karthik, B. \& Vijayaragavan, S.P. 2019, "Weight ward change region plummeting change for square based image huffman coding", International Journal of Innovative Technology and Exploring Engineering, vol. 8, no. 10, pp. 4313-4316.

2. Gowri Sankaran, B., Karthik, B. \& Vijayaragavan, S.P. 2019, "Image compression utilizing wavelet transform", International Journal of Innovative Technology and Exploring Engineering, vol. 8, no. 10, pp. 4305-4308.

3. Kandavel, N. \& Kumaravel, A. 2019, "Offloading computation for efficient energy in mobile cloud computing", International Journal of Innovative Technology and Exploring Engineering, vol. 8, no. 10, pp. 4317-4320.

4. Vinoth, V.V. \& Kanniga, E. 2019, "Reversible data hiding in encrypting images-an system", International Journal of Engineering and Advanced Technology, vol. 8, no. 6, pp. 3051-3053.

5. Selvapriya, B. \& Raghu, B. 2019, "Pseudocoloring of medical images: A research", International Journal of Engineering and Advanced Technology, vol. 8, no. 6, pp. 3712-3716.

6. Senthil Kumar, K. \& Muthukumaravel, A. 2019, "Bi-objective constraint and hybrid optimizer for the test case prioritization", International Journal of Engineering and Advanced Technology, vol. 8, no. 6, pp. 3436-3448.
7. Kavitha, G., Priya, N., Anuradha, C. \& Pothumani, S. 2019, "Read-write, peer-to-peer algorithms for the location-identity split", International Journal of Innovative Technology and Exploring Engineering, vol. 8, no. 9 Special Issue 3, pp. 445-447.

8. Kaliyamurthie, K.P., Michael, G., Anuratha, C. \& Sundaraj, B. 2019, "Certain improvements in alzheimer disease classification using novel fuzzy c means clustering for image segmentation", International Journal of Innovative Technology and Exploring Engineering, vol. 8, no. 9 Special Issue 3, pp. 599-604.

9. Kaliyamurthie, K.P., Sundarraj, B., Geo, A.V.A. \& Michael, G. 2019, "RIB: Analysis of I/O automata", International Journal of Innovative Technology and Exploring Engineering, vol. 8, no. 9 Special Issue 3, pp 1019-1022.

10. Velvizhi, R., Rajabhushanam, C. \& Vidhya, S.R.S. 2019, "Opinion mining for travel route recommendation using Social Media Networks (Twitter)", International Journal of Innovative Technology and Exploring Engineering, vol. 8, no. 9 Special Issue 3, pp. 508-512.

11. Kavitha, R., Sangeetha, S. \& Varghese, A.G. 2019, "Human activity patterns in big data for healthcare applications", International Journal of Innovative Technology and Exploring Engineering, vol. 8, no. 9 Special Issue 3, pp. 1101-1103.

12. Pothumani, S., Anandam, A.K., Sharma, N. \& Franklin, S. 2019 "Extended VEOT framework - Implemented in a smart boutique", International Journal of Innovative Technology and Exploring Engineering, vol. 8, no. 9 Special Issue 3, pp. 762-767.

13. Kaliyamurthie, K.P., Michael, G., Krishnan, R.M.V. \& Sundarraj, B. 2019, "Pseudorandom techniques for the internet", International Journal of Innovative Technology and Exploring Engineering, vol. 8, no. 9 Special Issue 3, pp. 915-918.

14. Aravindasamy, R., Jeffrin Rajan, M., Rama, A. \& Kavitha, P. 2019 , "Deep learning provisions in the matlab: Focus on CNN facility", International Journal of Innovative Technology and Exploring Engineering, vol. 8, no. 9 Special Issue 3, pp. 990-994.

15. Theivasigamani, S., Linda, M. \& Amudha, S. 2019, "Object sensing and its identification \& motion sensing", International Journal of Innovative Technology and Exploring Engineering, vol. 8, no. 9 Special Issue 3, pp. 545-549.

16. Mary Linda, I., Vimala, D. \& Shanmuga Priya, K. 2019, "A methodology for the emulation of IPv4", International Journal of Innovative Technology and Exploring Engineering, vol. 8, no. 9 Special Issue 3, pp. $848-852$

17. Velvizhi, R., Priya, D.J., Vimala, D. \& Linda, I.M. 2019, "Increased routing algorithm for mobile adhoc networks", International Journal of Innovative Technology and Exploring Engineering, vol. 8, no. 9 Special Issue 3, pp. 1606-1608

18. Sangeetha, S., Anuradha, C. \& Priya, N. 2019, "DNS in real world", International Journal of Innovative Technology and Exploring Engineering, vol. 8, no. 9 Special Issue 3, pp. 937-940.

19. Geetha, C., Vimala, D. \& Priya, K.S. 2019, "Constructing multi-processors and spreadsheets with SKIVE", International Journal of Innovative Technology and Exploring Engineering, vol. 8, no. 9 Special Issue 3, pp. 516-519.

20. Yugendhar, K., Sugumar, V. \& Kavitha, P. 2019, "A novel method of univac using fuzzy logic", International Journal of Innovative Technology and Exploring Engineering, vol. 8, no. 9 Special Issue 3, pp. 435-437.

21. Kaliyamurthie, K.P., Michael, G., Elankavi, R. \& Jijo, S.A. 2019, "Implementing aggregate-key for sharing data in cloud environment using cryptographic encryption", International Journal of Innovative Technology and Exploring Engineering, vol. 8, no. 9 Special Issue 3, pp. 957-959.

22. Jeffrin Rajan, M., Aravindasamy, R., Kavitha, P. \& Rama, A. 2019, "A novel method of object orientation variation in $\mathrm{C}++$ and java", International Journal of Innovative Technology and Exploring Engineering, vol. 8, no. 9 Special Issue 3, pp. 708-710.

23. Nayak, R., Dinesh, S. \& Thirunavukkarasu, S. 2019, "A novel method improvement of rapid miner for the data mining applications", International Journal of Innovative Technology and Exploring Engineering, vol. 8, no. 9 Special Issue 3, pp. 457-460.

24. Sivaraman, K., Krishnan, R.M.V., Sundarraj, B. \& Sri Gowthem, S 2019, "Network failure detection and diagnosis by analyzing syslog and SNS data: Applying big data analysis to network operations", International Journal of Innovative Technology and Exploring Engineering, vol. 8, no. 9 Special Issue 3, pp. 883-887.

25. Vimala, D., Linda, I.M. \& Priya, K.S. 2019, "Decoupling online algorithms from erasure coding in DNS", International Journal of Innovative Technology and Exploring Engineering, vol. 8, no. 9 Special Issue 3, pp. 950-953.

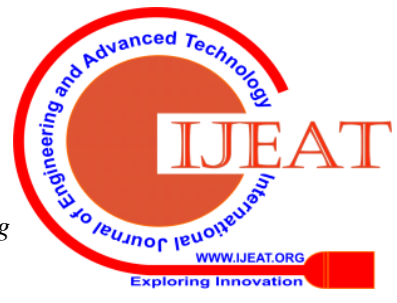


26. Rama, A., Kumaravel, A. \& Nalini, C. 2019, "Preprocessing medical images for classification using deep learning techniques", International Journal of Innovative Technology and Exploring Engineering, vol. 8, no. 9 Special Issue 3, pp. 711-716.

27. Sangeetha, S., Srividhya, S.R., Anita Davamani, K. \& Amudha, S. 2019, "A procedure for avoid overrun error in universal synchronous asynchronous receiver transmitter (usart) by utilizing dummy join and interrupt latency method", International Journal of Innovative Technology and Exploring Engineering, vol. 8, no. 9 Special Issue 3, pp. 657-660.

28. Aravindasamy, R., Jeyapriya, D., Sundarajan, B. \& Sangeetha, S. 2019, "Data duplication in cloud for optimal performance and security", International Journal of Innovative Technology and Exploring Engineering, vol. 8, no. 9 Special Issue 3, pp. 1156-1158.

29. Aravindasamy, R., Jeffrin Rajan, M., Sugumar, V. \& Kavitha, P. 2019, "A novel method on developing superblocks and the transistor using apodryal", International Journal of Innovative Technology and Exploring Engineering, vol. 8, no. 9 Special Issue 3, pp. 982-985.

30. Sasikumar, C.S. \& Kumaravel, A. 2019, "E-learning attributes selection through rough set theory and data mining", International Journal of Innovative Technology and Exploring Engineering, vol. 8, no. 10, pp. 3920-3924.

\section{AUTHORS PROFILE}

Shanmugapriya.K Assistant Professor, Department of Computer Science and Engineering,, Bharath Institute of Higher Education and Research, Chennai, India

Mary Linda.I Assistant Professor, Department of Computer Science and Engineering, Bharath Institute of Higher Education and Research, Chennai, India

Geetha.C, Assistant Professor, Department of Computer Science and Engineering,, Bharath Institute of Higher Education and Research, Chennai, India 